\title{
Abstinence from Chronic Cocaine Self-Administration Alters Striatal Dopamine Systems in Rhesus Monkeys
}

\author{
Thomas JR Beveridge', Hilary R Smith', Michael A Nader' and Linda J Porrino*,I \\ 'Department of Physiology and Pharmacology, Center for the Neurobiological Investigation of Drug Abuse, Wake Forest University School of \\ Medicine, Winston-Salem, NC, USA
}

\begin{abstract}
Although dysregulation within the dopamine (DA) system is a hallmark feature of chronic cocaine exposure, the question of whether these alterations persist into abstinence remains largely unanswered. Nonhuman primates represent an ideal model in which to assess the effects of abstinence on the DA system following chronic cocaine exposure. In this study, male rhesus monkeys self-administered cocaine $(0.3 \mathrm{mg} / \mathrm{kg}$ per injection, 30 reinforcers per session) under a fixed-interval 3-min schedule for 100 days followed by either 30 or 90 days abstinence. This duration of cocaine self-administration has been previously shown to decrease DA D2-like receptor densities and increase levels of DI-like receptors and DA transporters (DAT). Responding by control monkeys was maintained by food presentation under an identical protocol and the same abstinence periods. [ $\left.{ }^{3} \mathrm{H}\right] \mathrm{SCH} 23390$ binding to DA DI receptors following 30 days of abstinence was significantly higher in all portions of the striatum, compared to control animals, whereas [ $\left.{ }^{3} \mathrm{H}\right]$ raclopride binding to DA D2 receptors was not different between groups. $\left[{ }^{3} \mathrm{H}\right] \mathrm{WIN} 35428$ binding to DAT was also significantly higher throughout virtually all portions of the dorsal and ventral striatum following 30 days of abstinence. Following 90 days of abstinence, however, levels of DA DI receptors and DAT were not different from control values. Although these results indicate that there is eventual recovery of the separate elements of the DA system, they also highlight the dynamic nature of these components during the initial phases of abstinence from chronic cocaine self-administration.

Neuropsychopharmacology (2009) 34, II62-I I7I; doi: I0.1038/npp.2008.135; published online 3 September 2008
\end{abstract}

Keywords: cocaine; dopamine; autoradiography; abstinence; striatum

\section{INTRODUCTION}

Chronic cocaine use among human addicts has been associated with neuroadaptations in the dopamine (DA) system (Malison et al, 1998; Volkow et al, 1993, 1997). These include increases in the density of DA transporters (DAT) and decreases in the concentrations of DA D2-like receptors (Little et al, 1999; Mash et al, 2002; Volkow et al, 1993). In addition, alterations in DA release have also been observed. For example, investigators using positron emission tomography (PET) studies with $\left[{ }^{1 \mathrm{C}} \mathrm{C}\right]$ raclopride and methylphenidate have demonstrated decreases in DA release in the striatum of chronic cocaine users (Volkow et al, 1997; Wong et al, 2006). One problem, however, is that it is often difficult to exclude the influence of other factors such as the use of other illegal and legal drugs, differences in prior drug intake and use patterns, and differences in lifestyle. These differences, as well as the existence of conditions that may

*Correspondence: Dr LJ Porrino, Department of Physiology and Pharmacology, Center for the Neurobiological Investigation of Drug Abuse, Wake Forest University School of Medicine, Medical Center Boulevard, Winston-Salem, NC 27I57-1083, USA, Tel: + I 336716 8575, Fax: + I 336 716 850।, E-mail: Iporrino@wfubmc.edu Received 29 April 2008; revised 25 July 2008; accepted 30 July 2008 predate drug use, can limit the interpretation of studies in human patients.

Nonhuman primate models, in which variables can be systematically manipulated, represent an alternative approach to the study of the consequences of chronic cocaine self-administration and subsequent abstinence. Previous studies have demonstrated that chronic cocaine exposure is accompanied by significant decreases in the concentrations of DA D2 receptors as well as elevations in the levels of D1 receptors and the density of the DAT (Letchworth et al, 2001; Moore et al, 1998a, b; Nader et al, 2002, 2006). These effects mirror those seen in humans, thus substantiating the utility of these models of drug exposure.

Although there is considerable evidence for dysregulation of DA systems, it has proven more difficult to evaluate whether there is any evidence for recovery following cessation of drug use (Malison et al, 1998; Jacobsen et al, 2000; Volkow et al, 1993) or whether these changes persist beyond the time frame of continued cocaine exposure. Again, nonhuman primate models can provide insights into this phase of addiction. Farfel et al (1992) reported decreased concentrations of DAT and D1-like receptors in the striatum of monkeys following abstinence from chronic noncontingent exposure to cocaine. However, the specific role of abstinence was difficult to determine because of the 
lack of measurements in a group with no abstinence period. In a similar fashion, Melega et al (2008) reported significantly decreased levels of DAT in the striatum of vervet monkeys following 3 weeks of abstinence from an escalating methamphetamine regimen. The administration of stimulants in both studies, however, was noncontingent. The route of administration (contingent $v s$ noncontingent) has been shown to impact the brain differentially with respect to both DA release (Hemby et al, 1997) and glucose metabolism (Graham and Porrino, 1995; Porrino et al, 2002). Thus, the use of self-administration in the present study circumvents this issue. In addition, the effects of longterm cocaine self-administration on brain DA systems has been extensively studied using this model of self-administration in rhesus monkeys, thereby providing a baseline from which to assess the neuroadaptations that occur during abstinence.

The purpose of these studies, therefore, was to determine whether the changes in DAT and DA D1 and D2 receptor concentrations that have been demonstrated previously in animals exposed to cocaine self-administration (Letchworth et al, 2001; Moore et al, 1998a, b; Nader et al, 2002) would be reversed following extended periods of abstinence. On the basis of studies in human drug users (cf Volkow et al, 1993), we hypothesized that these changes in the DA system would persist even after 3 months of abstinence. To this end, monkeys self-administered cocaine for 100 sessions, with total intakes of $900 \mathrm{mg} / \mathrm{kg}$, followed by either 30 or 90 days of abstinence from the drug. DA D1 and D2 receptors, as well as the DAT, were measured with quantitative in vitro receptor autoradiography.

\section{METHODS}

\section{Subjects}

A total of 17 experimentally-naive adult male rhesus monkeys (Macaca mulatta) weighing between 7.7 and $13 \mathrm{~kg}$ (mean $\pm \mathrm{SD}, 10.2 \pm 1.32$ ) at the start of the study served as subjects. All procedures were performed in accordance with established practices as described in the National Institutes of Health Guide for Care and Use of Laboratory Animals. In addition, all procedures were reviewed and approved by the Animal Care and Use Committee of Wake Forest University. Monkeys were individually housed in stainless steel cages with water ad libitum; animals had physical and visual contact with each other. Their body weights were maintained at approximately $90-95 \%$ of free-feeding weights by banana-flavored pellets earned during the experimental sessions and by supplemental feeding of Lab Diet Monkey Chow, provided no sooner than $30 \mathrm{~min}$ post-session. In addition, they were given fresh fruit or peanuts at least three times per week. Each monkey was weighed once a week, and if necessary, their diets were adjusted to maintain stable weights.

\section{Behavioral Apparatus}

Experimental sessions were conducted in ventilated and sound-attenuated operant chambers $(1.5 \times 0.74 \times 0.76 \mathrm{~m}$; Med Associates Inc., East Fairfield, VT) designed to accommodate a primate chair (Model R001; Primate
Products, Redwood City, CA). The chamber contained an intelligence panel $(48 \times 69 \mathrm{~cm})$, which consisted of two retractable levers ( $5 \mathrm{~cm}$ wide) and three stimulus lights. The levers were positioned within easy reach of the monkey sitting in the primate chair. Banana-flavored food pellets (1 g; Bio-Serv, Frenchtown, NJ) were delivered from a feeder located on top of the chamber. A peristaltic infusion pump (7531-10; Cole-Parmer Co., Chicago, IL) was used to deliver drug injections at a rate of approximately $1 \mathrm{ml}$ per $10 \mathrm{~s}$ to those animals self-administering cocaine. Operation of the chambers and data acquisition was accomplished with a Power Macintosh computer system with an interface (Med Associates Inc.).

\section{Surgical Procedures}

All monkeys, including controls, were surgically prepared, under sterile conditions, with indwelling intravenous catheters and vascular access ports (Model GPV; Access Technologies, Skokie, IL). Monkeys were anesthetized with a combination of ketamine $(15 \mathrm{mg} / \mathrm{kg}, \mathrm{i} . \mathrm{m}$.) and butorphanol $(0.03 \mathrm{mg} / \mathrm{kg}, \mathrm{i} . \mathrm{m}$.$) and an incision was made near the$ femoral vein. After blunt dissection and isolation of the vein, the proximal end of the catheter was inserted into the vein for a distance calculated to terminate in the inferior vena cava. The distal end of the catheter was threaded subcutaneously to an incision made slightly off the midline of the back. The vascular access port was placed within a pocket formed by blunt dissection near this incision. Monkeys were given $24-48 \mathrm{~h}$ recovery time before returning to food-reinforced responding. Approximately 5 days before the terminal procedure, each monkey was implanted with a chronic indwelling catheter into the adjacent femoral artery for collection of timed arterial blood samples. The surgical procedures were identical to those described for the venous catheters. On the day of the final session, a terminal cerebral glucose metabolism study was conducted in which monkeys were injected with 2-[ $\left[{ }^{14} \mathrm{C}\right]$ deoxyglucose (2-DG) approximately 2 min after the end of the session and blood samples were obtained through the arterial catheter over a $45 \mathrm{~min}$ period (see Beveridge et al, 2006 for details). Metabolism data from these studies are not presented here.

\section{Self-Administration Procedures}

Monkeys were initially trained to respond on one of two levers by reinforcing each response on the correct lever with a food pellet. Over approximately a 3-week period the interval between availability of food pellets was gradually increased until a 3-min interval was achieved (ie fixedinterval 3-min schedule of reinforcement; FI 3-min). Under the final schedule conditions, the first response on the lever after $3 \mathrm{~min}$ resulted in the delivery of a food pellet; sessions ended after 30 food presentations. At the end of each session, the response levers were retracted, houselights and stimulus lights were extinguished, and animals remained in the darkened chamber for approximately $30 \mathrm{~min}$ before they were returned to their home cages. All monkeys responded under the FI 3-min schedule of food presentation for at least 20 sessions and until stable performance was obtained ( $\pm 20 \%$ of the mean for three consecutive sessions, with no trends in response rates). When food-maintained 
responding was stable, the feeder was unplugged and the effects of extinction on responding were examined for five consecutive sessions, after which responding was reestablished and maintained by food presentation.

After baseline performance had been established, all monkeys were surgically prepared with venous catheters, as described above, and randomly assigned to one of three groups. One group of monkeys served as controls and continued to respond under the FI 3-min schedule of food presentation for a total of 100 sessions $(N=6)$. The remaining 11 monkeys were assigned to the cocaine selfadministration groups $(0.3 \mathrm{mg} / \mathrm{kg}$ per injection). Because $0.3 \mathrm{mg} / \mathrm{kg}$ cocaine per injection was considered a high dose for previously cocaine-naive monkeys, for most animals this dose was achieved within two sessions by first allowing the monkey to self-administer $0.1 \mathrm{mg} / \mathrm{kg}$ cocaine. Food-maintained performance was allowed to stabilize after surgery (approximately 4-6 days) before cocaine self-administration sessions were begun. Before each experimental session, the back of the animal was cleaned with 95\% ethanol and betadine scrub and a 22 gauge Huber Point Needle (Model PG20-125) was inserted into the port leading to the venous catheter, connecting an infusion pump containing the cocaine solution to the catheter. Before the start of the session, the pump was operated for approximately $3 \mathrm{~s}$, filling the port with the dose of cocaine that was available during the experimental session. Sessions ended after 30 injections; as under control conditions, monkeys remained in the darkened chamber for approximately $30 \mathrm{~min}$. At the end of each session, the port was filled with heparinized saline $(100 \mathrm{U} / \mathrm{ml})$ to help prevent clotting.

Experimental sessions were conducted at approximately the same time each day and continued for a total of 100 sessions. Following the completion of the 100 sessions, an abstinence period of 30 or 90 days was introduced during which time catheters were flushed daily with heparinized saline, but no cocaine or food self-administration sessions were conducted. For the control group, abstinence periods of 30 days were imposed in four animals and 90 days in the two others. For the cocaine group, abstinence periods of 30 days were imposed on eight animals and 90 days on three animals. At the end of the period of abstinence one final self-administration session (food control or cocaine) was conducted and the 2-DG procedure was initiated immediately following the session. In two controls and four cocaine self-administration animals in the 30-day abstinence group, no cocaine was received at the final session. Animals were humanely killed with an overdose of pentobarbital $(100 \mathrm{mg} / \mathrm{kg}$, i.v.) at the end of the $45 \mathrm{~min}$ tracer uptake period.

\section{Tissue Processing}

After killing, brains were immediately removed, blocked, and frozen in isopentane at -35 to $-55^{\circ} \mathrm{C}$ and then stored at $-80^{\circ} \mathrm{C}$. The tissue blocks containing the striatum were then cut in a cryostat at $-20^{\circ} \mathrm{C}$ in the coronal plane into $20 \mu \mathrm{m}$ sections, collected onto electrostatically charged slides, desiccated under a vacuum overnight at $4{ }^{\circ} \mathrm{C}$, then stored at $-80^{\circ} \mathrm{C}$ until processed for autoradiography. Brain sections were collected from the portions of the caudate nucleus, putamen, and nucleus accumbens that lie rostral to the anterior commissure. This region is referred to as the precommissural striatum. Further, rostral and caudal levels of the precommissural striatum were designated with reference to the nucleus accumbens. The rostral precommissural striatum is the region where the nucleus accumbens is not differentiated into distinct shell and core subcompartments. The caudal precommissural striatum is the region congruent with the appearance of the shell and core of the nucleus accumbens, which is posterior to the emergence of the olfactory tubercle. For each of the binding studies, two adjacent sections were taken at each of five levels (two rostral and three caudal) through the precommissural striatum for a total of 10 sections per animal.

\section{D1 Receptor Binding}

DA D1 receptor binding site densities were determined with $\left[{ }^{3} \mathrm{H}\right] \mathrm{SCH} 23390$ (specific activity-85 Ci/mmol; PerkinElmer, Boston, MA) by quantitative in vitro receptor autoradiography according to procedures adapted from Lidow et al (1991) and Nader et al (2002). Sections were preincubated for $20 \mathrm{~min}$ in buffer $(50 \mathrm{mM}$ Tris, $120 \mathrm{mM}$ $\mathrm{NaCl}, 5 \mathrm{mM} \mathrm{KCl}, 2 \mathrm{mM} \mathrm{CaCl}_{2}, 1 \mathrm{mM} \mathrm{MgCl}_{2}, \mathrm{pH} 7.4,25^{\circ} \mathrm{C}$ ) to remove endogenous $\mathrm{DA}$, cocaine and $\left[{ }^{14} \mathrm{C}\right]$ from the $2-\mathrm{DG}$ procedure. Sections were then incubated for $30 \mathrm{~min}$ in the same buffer, $\mathrm{pH} 7.4,25^{\circ} \mathrm{C}$, containing $1 \mathrm{mM}$ ascorbic acid, $40 \mathrm{nM}$ ketanserin, and $1 \mathrm{nM}\left[{ }^{3} \mathrm{H}\right] \mathrm{SCH} 23390$. After incubation, sections were rinsed twice for $20 \mathrm{~s}$ in buffer containing $1 \mathrm{mM}$ ascorbic acid at $\mathrm{pH} 7.4,4{ }^{\circ} \mathrm{C}$, then dipped in distilled water at $4^{\circ} \mathrm{C}$, and dried under a stream of cool air. Nonspecific binding was defined by incubation of adjacent sections in the incubation solution in the presence of $5 \mu \mathrm{M}$ (+)-butaclamol. Sections, along with calibrated $\left[{ }^{3} \mathrm{H}\right]$ autoradiographic standards (Amersham, Piscataway, NJ), were apposed to Kodak Biomax MR film (Fisher Scientific, Pittsburgh, PA) for 6 weeks.

\section{D2 Receptor Binding}

The density and distribution of DA D2 receptor binding sites were determined with $\left[{ }^{3} \mathrm{H}\right]$ raclopride (specific activity, $87 \mathrm{Ci} / \mathrm{mmol}$; PerkinElmer) according to procedures adapted from Lidow et al (1991) and Nader et al (2002). Sections were preincubated for $20 \mathrm{~min}$ in buffer $(50 \mathrm{mM}$ Tris, $120 \mathrm{mM} \mathrm{NaCl}, 5 \mathrm{mM} \mathrm{KCl}, \mathrm{pH} 7.4,25^{\circ} \mathrm{C}$ ) to remove endogenous DA, cocaine, and $\left[{ }^{14} \mathrm{C}\right]$ from the 2-DG procedure. Slides were then incubated for $30 \mathrm{~min}$ in the same buffer, containing $5 \mathrm{mM}$ ascorbic acid and $2 \mathrm{nM}$ $\left[{ }^{3} \mathrm{H}\right]$ raclopride. Sections were rinsed $3 \times 2 \mathrm{~min}$ in buffer at $\mathrm{pH} 7.4,4^{\circ} \mathrm{C}$, then dipped in distilled water at $4^{\circ} \mathrm{C}$, and dried under a stream of cool air. Nonspecific binding was defined by incubation of adjacent sections in the incubation solution in the presence of $1 \mu \mathrm{M}(+)$-butaclamol. Sections, along with calibrated $\left[{ }^{3} \mathrm{H}\right]$ autoradiographic standards, were apposed to Kodak Biomax MR film for 8 weeks.

\section{Dopamine Transporter Binding}

The density of DAT binding sites was determined using $\left[{ }^{3} \mathrm{H}\right]$ WIN 35,428 (specific activity, $87 \mathrm{Ci} / \mathrm{mmol}$; PerkinElmer) autoradiography according to procedures adapted from Canfield et al (1990) and Letchworth et al (2001). Tissue sections were preincubated in buffer $(50 \mathrm{mM}$ Tris, 
$100 \mathrm{mM} \mathrm{NaCl}, \mathrm{pH} 7.4,4^{\circ} \mathrm{C}$ ) for $20 \mathrm{~min}$ to remove any residual $\mathrm{DA}$, cocaine, and $\left[{ }^{14} \mathrm{C}\right]$ from the 2 -DG procedure. Sections were then incubated for $2 \mathrm{~h}$ at $4{ }^{\circ} \mathrm{C}$ in the same buffer containing $5 \mathrm{nM}\left[{ }^{3} \mathrm{H}\right]$ WIN 35 428. Sections were rinsed for a total of $2 \mathrm{~min}$ in buffer at $4^{\circ} \mathrm{C}$, then dipped in distilled water at $4^{\circ} \mathrm{C}$, and dried under a stream of cold air. Nonspecific binding was defined by incubation of adjacent sections in the incubation solution in the presence of $30 \mu \mathrm{M}$ cocaine. Sections, along with calibrated $\left[{ }^{3} \mathrm{H}\right]$ autoradiographic standards, were apposed to Kodak Biomax MR film for 6 weeks.

\section{Densitometry and Data Analysis}

Films were developed with Kodak GBX developer, stopbath and Rapid Fixer (VWR, West Chester, PA), and then rinsed. Analysis of autoradiograms was conducted by quantitative densitometry with a computerized image processing system (MCID, Imaging Research; InterFocus Imaging Ltd, Cambridge, UK). Optical density values were converted to fmol/ mg (of wet-weight tissue) by reference to the calibrated $\left[{ }^{3} \mathrm{H}\right]$ standards. Specific binding was determined by digitally subtracting images of nonspecific binding from superimposed adjacent images of total binding. Structures were identified by Nissl staining of sections adjacent to those analyzed for receptor binding. Data from each assay were analyzed independently by means of a one-way analysis of variance followed by least-square differences post hoc tests for multiple comparisons. Each region consisted a separate analysis. Because binding data obtained from the control animals abstinent for 30 and 90 days were not significantly different from one another, similar to previous studies (Nader et al, 2002), data from the control groups were combined. In addition, there were no significant differences between the data from those animals who received cocaine and those that did not at their final session, so data from these groups were also combined.

\section{RESULTS}

\section{Effects of Abstinence from Chronic Cocaine Self-Administration for 30 Days}

Concentrations of $\left[{ }^{3} \mathrm{H}\right] \mathrm{SCH} 23390$ binding to DA D1 receptors in the precommissural striatum are shown in Table 1. Specific binding of $\left[{ }^{3} \mathrm{H}\right] \mathrm{SCH} 23390$ accounted for greater than $90 \%$ of total binding. Consistent with previous reports (Moore et al, 1998a; Nader et al, 2002), the binding of $\left[{ }^{3} \mathrm{H}\right] \mathrm{SCH} 23390$ to $\mathrm{D} 1$ receptors in non-drug-exposed control animals was heterogeneous with appreciable differences in the degree of binding among subregions of the striatum. Labeling was denser in the more rostral and medial portions throughout the striatum.

After 30 days of abstinence from cocaine exposure, binding to D1 receptors was characterized by widespread elevations across the entire rostral-caudal extent of the precommissural striatum, when compared to binding densities in non-drug-exposed control animals (Table 1; Figure 1). In the more rostral striatum, concentrations were significantly higher in the caudate nucleus including the dorsolateral $(+27 \%)$, central $(+27 \%)$, dorsomedial $(+27 \%)$, and ventromedial $(+23 \%)$ portions, as well as in
Table I Effect of 30 or 90 Days of Abstinence Following Chronic Cocaine Self-Administration on Densities of $\left[{ }^{3} \mathrm{H}\right] \mathrm{SCH} 23390$ Binding to DI Receptors in Precommissural Striatum of Rhesus Monkeys

\begin{tabular}{|c|c|c|c|}
\hline \multirow[t]{2}{*}{ Brain region } & \multirow{2}{*}{$\begin{array}{l}\text { Food controls } \\
\qquad(N=6)\end{array}$} & \multicolumn{2}{|c|}{ Abstinence } \\
\hline & & $\begin{array}{l}30 \text { days } \\
(N=8)\end{array}$ & $\begin{array}{l}90 \text { days } \\
(N=3)\end{array}$ \\
\hline \multicolumn{4}{|l|}{ Rostral } \\
\hline \multicolumn{4}{|l|}{ Caudate } \\
\hline Dorsolateral & $104 \pm 8.3$ & $|3| \pm 4.3 * *$ & $114 \pm 5.9$ \\
\hline Central & $112 \pm 7.3$ & $142 \pm 4.0$ ***** & $116 \pm 0.4$ \\
\hline Dorsomedial & $127 \pm 11.5$ & $|6| \pm 4.5 * * *$ & $125 \pm 4.6$ \\
\hline Ventromedial & $113 \pm 5.9$ & $139 \pm 2.7$ ******* & $113 \pm 1.1$ \\
\hline \multicolumn{4}{|l|}{ Putamen } \\
\hline Dorsal & $12 \mid \pm 8.4$ & $|4| \pm 3.3^{*}$ & $116 \pm 8.3$ \\
\hline Central & $120 \pm 6.8$ & $147 \pm 1.8$ ******** & || $\mid \pm 4.2$ \\
\hline Ventral & $113 \pm 4.9$ & $139 \pm 2.0 *$ ***** & $107 \pm 3.4$ \\
\hline $\begin{array}{l}\text { Nucleus } \\
\text { accumbens }\end{array}$ & $98 \pm 7.0$ & $120 \pm 4.3 * *$ & $102 \pm 3.2$ \\
\hline \multicolumn{4}{|l|}{ Caudal } \\
\hline \multicolumn{4}{|l|}{ Caudate } \\
\hline Dorsolateral & $95 \pm 7.1$ & $124 \pm 4.0 *$ ****** & $101 \pm 4.6$ \\
\hline Central & $105 \pm 7.6$ & $136 \pm 4.9 *$ ***** & $109 \pm 5.3$ \\
\hline Dorsomedial & $123 \pm 11.0$ & $160 \pm 5.5 * * *$ & $120 \pm 6.9$ \\
\hline Ventromedial & $100 \pm 7.1$ & $117 \pm 3.8 *$ & $103 \pm 2.2$ \\
\hline \multicolumn{4}{|l|}{ Putamen } \\
\hline Dorsal & $101 \pm 7.6$ & $124 \pm 6.7 *$ & $106 \pm 3.1$ \\
\hline Central & $98 \pm 5.6$ & $127 \pm 5.5$ ******* & $109 \pm 1.7$ \\
\hline Ventral & $95 \pm 4.2$ & $122 \pm 4.6$ ****** & $106 \pm 4.6$ \\
\hline \multicolumn{4}{|l|}{$\begin{array}{l}\text { Nucleus } \\
\text { accumbens }\end{array}$} \\
\hline Core & $61 \pm 1.9$ & $89 \pm 4.6 * * * *$ & $7 \mid \pm 4.3$ \\
\hline Shell & $78 \pm 5.1$ & $94 \pm 5.4 *$ & $83 \pm 2.9$ \\
\hline Olfactory tubercle & $97 \pm 6.2$ & $123 \pm 6.0 * * *$ & $117 \pm 8.4$ \\
\hline
\end{tabular}

Mean (SEM) data sampled at two levels of the striatum (rostral and caudal) are presented as specific binding in fmols/mg of wet-weight tissue.

${ }^{*} p<0.05$, *** $p<0.01$, **** $p<0.00$ I different from food control, one-way ANOVA followed by a post hoc least-squares difference test comparing abstinence groups to food controls.

the dorsal $(+17 \%)$, central $(+22 \%)$, and ventral $(+23 \%)$ portions of the putamen, when compared to the densities in non-drug-exposed controls animals. Significant elevations were also evident in the nucleus accumbens $(+23 \%)$ at this level. At the level of the striatum where the core and shell of the nucleus accumbens are most differentiated, densities of D1-like receptors were also significantly higher throughout the dorsolateral $(+31 \%)$, central $(+29 \%)$, dorsomedial $(+30 \%)$, and ventromedial $(+18 \%)$ caudate nucleus, as well as the dorsal $(+23 \%)$, central $(+29 \%)$, and ventral $(+28 \%)$ putamen, as compared to densities of non-drugexposed controls. Within the ventral striatum at this level, the concentration of $D_{1}$ receptor binding sites was higher in 

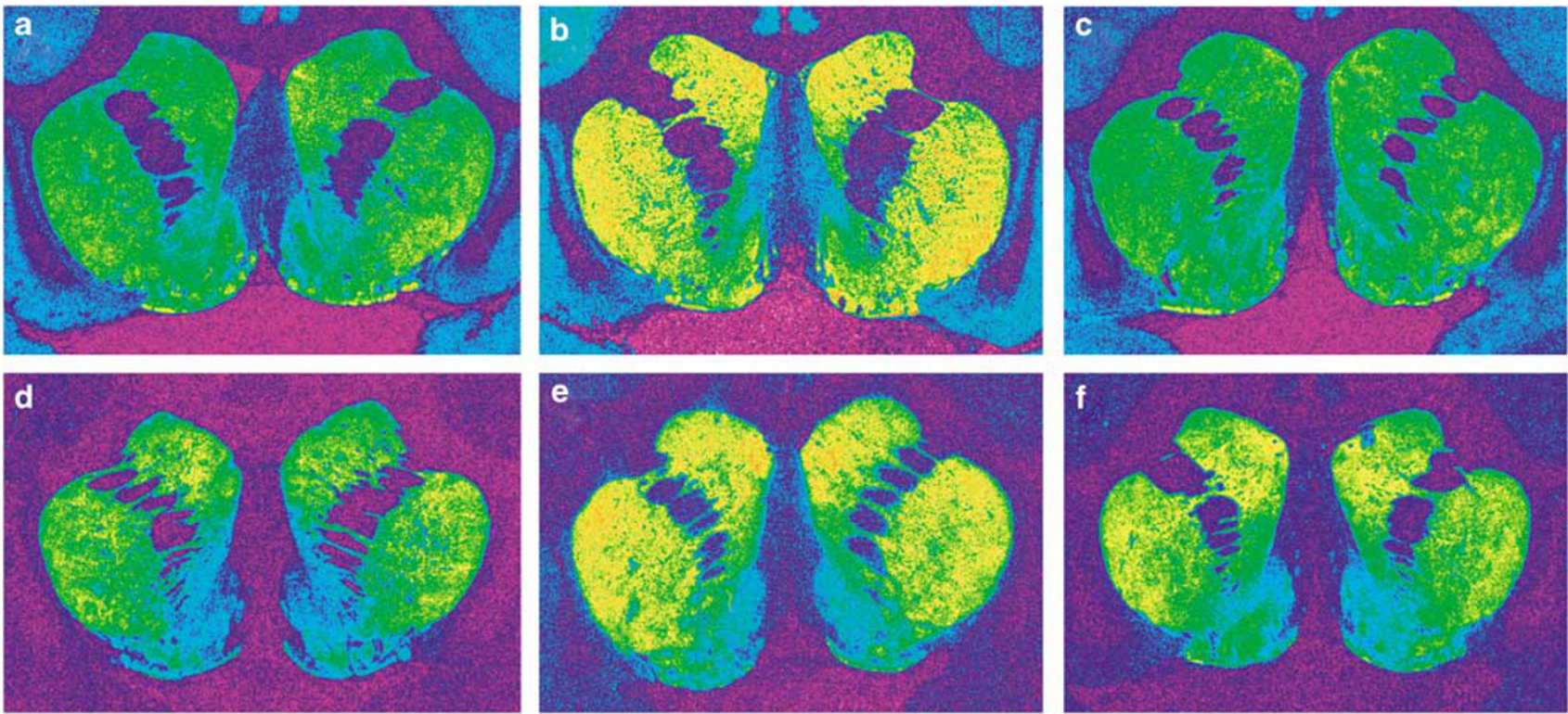

Figure I Representative autoradiograms of $\left[{ }^{3} \mathrm{H}\right] \mathrm{SCH} 23390$ binding to DI receptors (top panel) and $\left[{ }^{3} \mathrm{H}\right]$ WIN 35428 binding to dopamine transporters (bottom panel) in coronal sections of rhesus monkey striatum. (a, d) Control animal responding for food reinforcement. (b, e) Cocaine self-administration animal with 30 days abstinence. (c, f) Cocaine self-administration animal with 90 days abstinence.

the nucleus accumbens core $(+45 \%)$ and shell $(+20 \%)$, as well as in the olfactory tubercle $(+26 \%)$, as compared to the densities in controls.

Concentrations of $\left[{ }^{3} \mathrm{H}\right]$ raclopride binding to DA D2 receptors in the precommissural striatum are shown in Table 2. Specific binding with $\left[{ }^{3} \mathrm{H}\right]$ raclopride accounted for greater than $90 \%$ of total binding. The distribution of $\left[{ }^{3} \mathrm{H}\right]$ raclopride binding to D2 receptors was also heterogeneous across subregions of the dorsal and ventral striatum as in previous reports (Moore et al, 1998b; Nader et al, 2002). In the non-drug-exposed controls, higher concentrations of D2 binding sites were present in the dorsal as compared to the ventral striatum. In addition, there was evidence of a medial to lateral gradient with the higher concentrations of binding sites present in the more lateral portions of the striatum.

After 30 days of abstinence, levels of D2 receptor binding in cocaine-exposed and food-reinforced animals were not significantly different from one another in most regions of the striatum. Higher concentrations of binding sites were observed in the ventral putamen $(+10 \%)$ and anterior nucleus accumbens $(+12 \%)$ in tissue from the cocaineexposed monkeys compared to controls. No other significant differences were noted.

Concentrations of $\left[{ }^{3} \mathrm{H}\right]$ WIN 35428 binding to DAT in the precommissural striatum are shown in Table 3. Consistent with previous reports (Letchworth et al, 2001), binding to DAT sites in non-drug-exposed animals was higher in dorsal as compared to ventral striatum. Within the nucleus accumbens, higher densities were observed in the core as compared to the shell divisions. Finally, nonspecific binding accounted for less than $10 \%$ of the total.

After 30 days of abstinence from cocaine exposure, binding to the DAT was significantly higher throughout the majority of regions of the striatum rostral to the anterior commissure when compared to binding in non-drugexposed control animals (Figure 1). Specifically, the concentrations of DAT binding sites at rostral levels were significantly higher in central $(+22 \%)$, dorsomedial $(+25 \%)$, and ventromedial $(+28 \%)$ caudate nucleus, and in the dorsal $(+16 \%)$ and central $(+23 \%)$ putamen, compared to food-reinforced controls. In addition, there was also significantly higher binding to DAT in the anterior nucleus accumbens $(+37 \%)$ in cocaine- compared to foodreinforced monkeys. Within the more caudal portions of the precommissural striatum, densities of DAT binding sites were significantly higher in the central caudate nucleus $(+21 \%)$, and putamen, central $(+20 \%)$ and ventral $(+19 \%$; Figure 1). Within the ventral striatum at this level, binding to DAT was significantly higher in the nucleus accumbens core $(+20 \%)$ and olfactory tubercle $(+24 \%)$ in tissue from cocaine- $v s$ food-reinforced monkeys.

\section{Effects of Abstinence from Chronic Cocaine Self-Administration for 90 Days}

In contrast to the widespread differences in the density of D1 receptor binding sites observed in cocaine-exposed animals following 30 days of abstinence, after 90 days of abstinence, there were no significant differences when compared to food-reinforced controls in any portion of the precommissural striatum (Table 1; Figure 1). Similarly, concentrations of $\left[{ }^{3} \mathrm{H}\right]$ raclopride binding to DA D2 receptors in the precommissural striatum after 90 days of abstinence were also not significantly different from those in non-drug-exposed animals (Table 2).

The concentrations of $\left[{ }^{3} \mathrm{H}\right]$ WIN 35428 binding to DAT exhibited a similar pattern to that observed with D1 and D2 receptors. There were no significant differences in the density of DAT between cocaine-exposed monkeys following 90 days of abstinence as compared to levels in nondrug-exposed controls (Table 3; Figure 1), although it should be noted that there was a trend toward higher levels of binding in the anterior nucleus accumbens. 
Table 2 Effect of 30 or 90 Days of Abstinence Following Chronic Cocaine Self-Administration on Densities of $\left[{ }^{3} \mathrm{H}\right]$ raclopride Binding to D2 Receptors in Precommissural Striatum of Rhesus Monkeys

\begin{tabular}{|c|c|c|c|}
\hline \multirow[t]{2}{*}{ Brain region } & \multirow{2}{*}{$\begin{array}{l}\text { Food controls } \\
\qquad(N=6)\end{array}$} & \multicolumn{2}{|c|}{ Abstinence } \\
\hline & & $\begin{array}{l}30 \text { days } \\
(N=8)\end{array}$ & $\begin{array}{l}90 \text { days } \\
(N=3)\end{array}$ \\
\hline \multicolumn{4}{|l|}{ Rostral } \\
\hline \multicolumn{4}{|l|}{ Caudate } \\
\hline Dorsolateral & $78 \pm 1.4$ & $86 \pm 3.5$ & $81 \pm 3.0$ \\
\hline Central & $82 \pm 2.7$ & $89 \pm 2.8$ & $86 \pm 3.0$ \\
\hline Dorsomedial & $83 \pm 2.2$ & $90 \pm 2.5$ & $90 \pm 4.0$ \\
\hline Ventromedial & $77 \pm 1.1$ & $83 \pm 2.4$ & $84 \pm 4.6$ \\
\hline \multicolumn{4}{|l|}{ Putamen } \\
\hline Dorsal & $93 \pm 2.1$ & $96 \pm 3.3$ & $93 \pm 5.5$ \\
\hline Central & $87 \pm 1.9$ & $94 \pm 3.0$ & $89 \pm 6.3$ \\
\hline Ventral & $80 \pm 2.0$ & $88 \pm 2.4 *$ & $81 \pm 5.9$ \\
\hline Nucleus accumbens & $72 \pm 1.0$ & $81 \pm 2.6 *$ & $79 \pm 4.4$ \\
\hline \multicolumn{4}{|l|}{ Caudal } \\
\hline \multicolumn{4}{|l|}{ Caudate } \\
\hline Dorsolateral & $79 \pm 2.8$ & $83 \pm 3.0$ & $81 \pm 3.1$ \\
\hline Central & $83 \pm 3.6$ & $89 \pm 3.6$ & $84 \pm 3.2$ \\
\hline Dorsomedial & $84 \pm 3.8$ & $87 \pm 3.3$ & $85 \pm 4.2$ \\
\hline Ventromedial & $60 \pm 4.1$ & $59 \pm 3.0$ & $62 \pm 2.3$ \\
\hline \multicolumn{4}{|l|}{ Putamen } \\
\hline Dorsal & $93 \pm 3.0$ & $96 \pm 4.1$ & $94 \pm 5.7$ \\
\hline Central & $86 \pm 3.6$ & $91 \pm 3.4$ & $86 \pm 5.0$ \\
\hline Ventral & $78 \pm 4.1$ & $82 \pm 3.1$ & $76 \pm 4.8$ \\
\hline \multicolumn{4}{|l|}{ Nucleus accumbens } \\
\hline Core & $53 \pm 3.5$ & $56 \pm 1.8$ & $51 \pm 2.3$ \\
\hline Shell & $56 \pm 3.1$ & $57 \pm 3.4$ & $47 \pm 3.1$ \\
\hline
\end{tabular}

Mean (SEM) data sampled at two levels of the striatum (rostral and caudal) are presented as specific binding in fmols/mg of wet-weight tissue.

* $p<0.05$ different from food control, one-way ANOVA followed by a post hoc least-squares difference test comparing abstinence groups to food controls.

\section{DISCUSSION}

Previous studies from our group have shown that chronic exposure to cocaine self-administration is accompanied by significant dysregulation of the DA system of nonhuman primates (Letchworth et al, 2001; Moore et al, 1998a,b; Nader et al, 2002, 2006). The results of the present study demonstrate that this dysregulation remains evident after cessation of cocaine exposure. Following 30 days of abstinence, the concentrations of DA D1 receptors and the DAT were significantly elevated throughout the striatum of monkeys with histories of chronic cocaine self-administration when compared to food-reinforced controls. However, the present study also provides clear evidence for recovery within the DA system after more prolonged periods of abstinence ( 90 days), as evidenced by the lack of significant differences between cocaine-exposed and controls animals at this time point. These data suggest that cocaine exposure
Table 3 Effect of 30 or 90 Days of Abstinence Following Chronic Cocaine Self-Administration on Densities of $\left.{ }^{3}{ }^{H} \mathrm{H}\right] \mathrm{WIN} 35428$ Binding to DAT in Precommissural Striatum of Rhesus Monkeys

\begin{tabular}{|c|c|c|c|}
\hline \multirow[t]{2}{*}{ Brain region } & \multirow{2}{*}{$\begin{array}{l}\text { Food controls } \\
\qquad(N=6)\end{array}$} & \multicolumn{2}{|c|}{ Abstinence } \\
\hline & & $\begin{array}{l}30 \text { days } \\
(N=8)\end{array}$ & $\begin{array}{l}90 \text { days } \\
(N=3)\end{array}$ \\
\hline \multicolumn{4}{|l|}{ Rostral } \\
\hline \multicolumn{4}{|l|}{ Caudate } \\
\hline Dorsolateral & $82 \pm 5.2$ & $94 \pm 4.8$ & $87 \pm 10.3$ \\
\hline Central & $94 \pm 6.9$ & $114 \pm 6.6^{*}$ & $100 \pm 11.8$ \\
\hline Dorsomedial & $95 \pm 5.3$ & $118 \pm 7.8^{*}$ & $10 \mid \pm 10.8$ \\
\hline Ventromedial & $86 \pm 6.6$ & $109 \pm 5.8^{*}$ & $94 \pm 11.0$ \\
\hline \multicolumn{4}{|l|}{ Putamen } \\
\hline Dorsal & $103 \pm 6.0$ & $120 \pm 4.9 *$ & $118 \pm 11.3$ \\
\hline Central & $94 \pm 7.0$ & $116 \pm 6.5 *$ & $108 \pm 13.8$ \\
\hline Ventral & $82 \pm 8.3$ & $99 \pm 5.9$ & $85 \pm 14.9$ \\
\hline Nucleus accumbens & $42 \pm 5.2$ & $58 \pm 4.5^{*}$ & $62 \pm 5.0$ \\
\hline \multicolumn{4}{|l|}{ Caudal } \\
\hline \multicolumn{4}{|l|}{ Caudate } \\
\hline Dorsolateral & $90 \pm 6.0$ & $96 \pm 3.9$ & $105 \pm 9.0$ \\
\hline Central & $103 \pm 7.1$ & $124 \pm 4.7 *$ & $118 \pm 7.6$ \\
\hline Dorsomedial & $109 \pm 7.7$ & $|2| \pm 5.2$ & $125 \pm 11.5$ \\
\hline Ventromedial & $78 \pm 8.4$ & $96 \pm 4.9$ & $91 \pm 7.4$ \\
\hline \multicolumn{4}{|l|}{ Putamen } \\
\hline Dorsal & $108 \pm 5.5$ & $120 \pm 5.5$ & $128 \pm 9.9$ \\
\hline Central & $95 \pm 4.3$ & $114 \pm 4.6$ *** & $111 \pm 3.8$ \\
\hline Ventral & $87 \pm 4.6$ & $103 \pm 5.0 *$ & $100 \pm 4.2$ \\
\hline \multicolumn{4}{|l|}{ Nucleus accumbens } \\
\hline Core & $43 \pm 3.7$ & $51 \pm 2.5$ & $53 \pm 5.4$ \\
\hline Shell & $32 \pm 1.3$ & $40 \pm 2.5^{*}$ & $36 \pm 2.4$ \\
\hline Olfactory tubercle & $50 \pm 3.3$ & $62 \pm 2.7^{*}$ & $54 \pm 3.3$ \\
\hline
\end{tabular}

Mean (SEM) data sampled at two levels of the striatum (rostral and caudal) are presented as specific binding in fmols/mg of wet-weight tissue.

${ }^{*} p<0.05$, *** $p<0.01$ different from food control, one-way ANOVA followed by a post hoc least-squares difference test comparing abstinence groups to food controls.

may not produce permanent alterations in the DA system, but that recovery may occur with prolonged abstinence from drug use.

The dysregulation of DAT concentrations shown here following abstinence is consistent with previous reports in nonhuman primates (Letchworth et al, 2001), which showed significant elevations in the densities of DAT binding sites in both ventral and dorsal striatum. Although not explicitly tested, it appears that after cessation of drug exposure the elevations in DAT binding site density are at least as great in magnitude and more widespread across the regions of the striatum than those reported without any withdrawal period (Letchworth et al, 2001). Similarly, the elevated concentrations of $\mathrm{D} 1$ receptor binding sites observed here following 30 days of abstinence are also consistent with previous studies that showed increased D1-like receptor binding densities in the 
striatum of nonhuman primates exposed to an identical regimen of cocaine self-administration (Nader et al, 2002). In contrast there were no significant differences observed between the levels of D2-like receptor binding densities in the striatum of cocaine-exposed and control animals. This lack of dysregulation was present, despite the large decreases in the concentrations of $\mathrm{D} 2$ receptors that have been reported in both human addicts (Volkow et al, 1993) and animal models of cocaine self-administration (Moore et al, 1998a, b; Nader et al, 2002, 2006). The present data, then, suggest a more rapid normalization to control levels in this system as compared to D1-like receptors and the DAT. Taken together, the changes in DA receptors and the DAT clearly show that the period immediately following cessation of cocaine self-administration is highly labile with considerable changes in the regulation of the DA system taking place, but that this is followed by re-regulation of the system approaching a more normal distribution of DA receptors and the DAT after more prolonged abstinence.

\section{D1 Receptor Changes}

The widespread elevations in the density of D1 receptors observed here after the cessation of cocaine use are consistent with reports demonstrating an increased sensitivity of D1 receptors during withdrawal. Measurement of D1 sensitivity was undertaken in a study by Henry and White (1991), in which single unit recordings of neurons in the nucleus accumbens were found to be more sensitive to the D1 receptor agonist SKF 38393 following chronic daily injections of cocaine compared to saline-treated controls. This effect was persistent, in that increased sensitivity remained evident up to one month into withdrawal. The authors hypothesized that the D1 receptor sensitization was due to D2 autoreceptor subsensitivity in the somatodendritic A10 area, thereby reducing inhibitory impulse flow throughout the mesoaccumbens DA system (Henry and White, 1991). The data from the present study suggest increased D1 receptor binding sites in abstinence, which could explain this increased sensitivity of dopaminergic neurons to a direct-acting D1 receptor agonist. Furthermore, the enhanced effect of SKF 38393 on nucleus accumbens neurons was not apparent two months following withdrawal, suggesting that there was recovery of the D1 receptor sensitivity (Henry and White, 1991); an outcome consistent with the recovery of D1 receptor densities noted in the present study after 90 days of abstinence. Other reports also support an important role for D1 receptors in relapse. The direct stimulation of $\mathrm{D} 1$ receptors in the shell of the nucleus accumbens can reinstate cocaine seeking in abstinent rodents (Schmidt et al, 2006). However, the literature is somewhat inconsistent in that both D1 agonists and antagonists can attenuate drug seeking elicited by cocaine primes or cocaine-related stimuli (Alleweireldt et al, 2002; De Vries et al, 1999; Khroyan et al, 2000; Self et al, 1996; Weiss et al, 2001). Recently, Khroyan et al (2003) reported that D1 agonists and antagonists reduce relapse in a nonhuman primate model of cocaine seeking. These authors suggested that there may be a critical range of D1 receptor activity necessary for cocaine seeking, and that both antagonists and agonists could shift activity out of this window. The increased concentrations of D1 receptors that accompany abstinence might modify this range, resulting in an alteration in the sensitivity of this system. Another consideration is that D1 activity may act to modulate activity at D2 receptors (Nolan et al, 2007; Ruskin et al, 1999; Walters et al, 1987). The present data suggest that the ratio of $\mathrm{D} 1$ to $\mathrm{D} 2$ receptors shifts during the course of abstinence and may thereby alter the efficacy of this modulation.

Although, in contrast to the present data, there have been reports of decreased levels of D1 receptors following chronic cocaine self-administration (Moore et al, 1998a), considerable differences exist between these studies, such as dose and length of exposure to cocaine, total intake, and comparative control groups. Taken together, therefore, converging evidence strongly indicates that the D1 system is in considerable flux following withdrawal from chronic cocaine administration.

\section{Dopamine Transporter Changes}

The findings of elevated concentrations of DAT across the striatum of cocaine-exposed animals after cessation of drug use extend those of our previous studies showing increased levels of DAT binding sites that accompany cocaine selfadministration in nonhuman primates. The present data demonstrate that this dysregulation persists during the initial phases of abstinence. Furthermore, they suggest that recovery to control levels follows a relatively long time course (up to 90 days in the present study). In our previous studies we showed that although initially restricted to largely ventral striatal regions, changes in the density of DAT binding sites expanded to encompass more dorsal and rostral portions of the striatum with longer periods of exposure to cocaine (Letchworth et al, 2001; Porrino et al, 2004). In the present study the return to control levels of DAT concentrations during abstinence appeared to be greater and more rapid in the dorsal striatum than in the ventral striatum, and thus seemed to follow a reverse anatomical trajectory to the pattern of effects induced by chronic cocaine exposure.

The present data are also consistent with reports in human cocaine users (Little et al, 1999; Malison et al, 1998; Mash et al, 2002; Staley et al, 1994) that have shown elevated levels of binding to DAT sites in the striatum compared to controls, with the most marked increases located in the ventral striatum. Recently, these elevations have been shown to be accompanied by significant decreases in vesicular monoamine transporter 2 (VMAT2) binding (Little et al, 2003), suggestive of an actual loss of DA neurons. The authors concluded that the elevated DAT was likely directly due to a compensatory response to the pharmacological blockade by cocaine, whereas the decreases in VMAT2 more likely reflected overall changes in DA metabolism, resulting in hypodopaminergic function.

Human cocaine addicts have been reported to have reduced DA concentrations in the ventral striatum, as measured with PET, in response to methylphenidate challenge when compared to healthy controls (Volkow et al, 1997). Recently, Martinez et al (2007) reported that cocaine users had a blunted response to an amphetamine challenge in the ventral striatum and putamen. Furthermore, this decrease in amphetamine-induced DA release 
was correlated with the choice for cocaine in separate selfadministration sessions, such that those users with the lowest degree of DA release in response to amphetamine were most likely to choose cocaine over an alternative reinforcer (Martinez et al, 2007). Recent studies in rodent models of cocaine use support this idea as well. Mateo et al (2005), for example, reported that exposure to chronic cocaine self-administration is associated with alterations in DAT function. These investigators showed that baseline DA uptake was increased, resulting in more rapid clearance of synaptic DA, and therefore, decreased basal levels of extracellular DA, or a hypodopaminergic state. Thus, it is likely that the increased DAT concentrations following withdrawal from chronic cocaine self-administration observed in the present study represent a compensatory response, resulting in lower baseline levels of extracellular DA.

\section{D2 Receptor Changes}

One result from the present study was that the concentrations of D2 receptor levels had returned to control values following 30 days of abstinence, compared to the significant decreases observed in animals with no withdrawal period (Nader et al, 2002). In contrast to the present investigation, human imaging studies have generally found that D2 receptor levels are lower than those of controls following prolonged abstinence from chronic cocaine exposure (Martinez et al, 2004; Volkow et al, 1993). Potential explanations of the differences between these human studies and the present nonhuman primate investigation include differences in the pattern and duration of cocaine intake, as well as the possibility of preexisting lower levels of D2 receptors in human addicts. Consistent with the latter idea, there is evidence to suggest that lower basal levels of D2 receptors in healthy humans predict increased reinforcing efficacy of stimulants such as methylphenidate (Volkow et al, 1999), and similarly in monkeys, baseline levels of D2 receptors predicted the propensity to self-administer cocaine (Morgan et al, 2002; Nader et al, 2006). In keeping with the parallel nature of these findings across species, both human (Volkow et al, 1993) and nonhuman primate (Nader et al, 2006) imaging studies have demonstrated lower levels of D2 receptor availability following abstinence from cocaine exposure. Notably, the schedule of cocaine self-administration in the latter experiment (Nader et al, 2006) was similar to the schedule of reinforcement used in this study. Thus, the dissimilar outcomes from these two studies are unlikely to have been due to methodological differences, such as the schedule of reinforcement or cumulative intake during cocaine self-administration.

A more likely explanation involves the functional dynamics of the DA system. Measures of D2 receptor availability with PET have been described as 'functional' because the signal is related to the amount of protein (in this case densities of D2 receptors) and the levels of circulating neurotransmitter (see Laruelle, 2000; Nader and Czoty, 2008 for further discussion). In contrast, receptor autoradiography is uncontaminated by circulating levels of DA. Thus, the present study, along with our earlier work, suggests that D2 receptor densities are decreased by cocaine self-administration, but the receptor levels appear to recover during abstinence. In a similarly conducted PET study (Nader et al, 2006), recovery was noted in three of five monkeys. The present findings suggest that these monkeys were probably not different in D2 receptor densities, but perhaps the responsiveness of the DA system (ie levels of circulating DA during abstinence) differentiated between 'recovered' and 'nonrecovered' subjects.

\section{Limitations}

One important limitation of the current studies is that our studies cannot address the functionality of the D1 and D2 receptors or of the DAT. Rather we examined only the changes in the density of receptor proteins. Although the results have implications for the potential roles of these systems, further studies will be required to shed light on the behavioral consequences of the changes shown here. Another limitation of the present study is that autoradiographic ligands often fail to dissociate between intracellular and cytoplasmic locations of their targets, as radiolabeled antagonists are often membrane permeable. Little et al (2002) demonstrated that chronic exposure to cocaine leads to a significant upregulation of DAT at the membrane surface, concurrent with a decrease in the intracellular DAT concentration, in transfected cells. Recently, Samuvel et al (2008) reported a similar finding in rat striatal synaptosomal preparations. These results suggest that the alterations in the DAT distribution observed in the present study may represent changes at the membrane surface, rather than intracellular sites.

Finally, some caution should be given to the interpretation of the studies of prolonged (90 days) abstinence, as these findings were based on a relatively small group of animals $(N=3)$. Despite the small number of subjects, the data obtained from this group were rather consistent, as can be seen in a scatter plot shown in Figure 2. The concentration of $\mathrm{D} 1$ receptor binding sites across the striatum showed little variability within groups, suggesting the reliability of these findings. Similar consistency was also

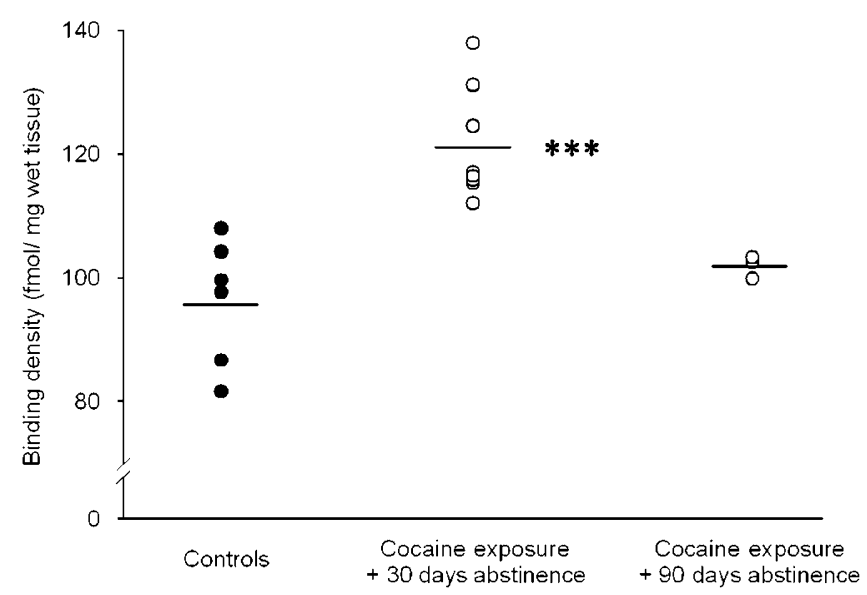

Figure 2 Binding densities of DI receptors for individual animals averaged across the entire striatum following either food reinforcement (controls), or 30 or 90 days abstinence from chronic cocaine selfadministration. Means for groups are depicted with black bars, $* * * p<0.001$ compared to food-reinforced controls. 
evident in data from D2 receptor and DAT binding assays. Although caution should be exercised, these data strongly suggest that restoration of concentrations of DAT and DA receptors within the striatum can occur with prolonged abstinence.

\section{CONCLUSIONS}

In conclusion, exposure to cocaine self-administration produced significant alterations in the regulation of DA systems that persisted during the early phases (first 30 days) of abstinence. This was most evident in the regulation of the concentration of D1 receptors and the DAT, both in terms of their magnitude of alterations and their topographical extent. In contrast, there was evidence for normalization with longer durations of abstinence from cocaine exposure, in that the concentrations of DAT, D1, and D2 receptors after 90 days of abstinence did not differ from those of nondrug-exposed controls. These systems, however, do not necessarily follow the same temporal course of recovery, suggesting that there is likely to be some instability in the regulation of DA levels particularly early in abstinence. This dopaminergic dysregulation may impact the effectiveness of any potential pharmacotherapy administered to abstinent cocaine addicts, particularly if the medication relies on the DA system for its mechanism of action.

\section{ACKNOWLEDGEMENTS}

This work was supported by NIDA grant DA 09085 (LJP).

\section{DISCLOSURE/CONFLICT OF INTEREST}

The authors have no conflict of interest to disclose.

\section{REFERENCES}

Alleweireldt AT, Weber SM, Kirschner KF, Bullock BL, Neisewander JL (2002). Blockade or stimulation of D1 dopamine receptors attenuates cue reinstatement of extinguished cocaine-seeking behavior in rats. Psychopharmacology (Berl) 159: 284-293.

Beveridge TJ, Smith HR, Daunais JB, Nader MA, Porrino LJ (2006). Chronic cocaine self-administration is associated with altered functional activity in the temporal lobes of non human primates. Eur J Neurosci 23: 3109-3118.

Canfield DR, Spealman RD, Kaufman MJ, Madras BK (1990). Autoradiographic localization of cocaine binding sites by $[3 \mathrm{H}] \mathrm{CFT}([3 \mathrm{H}] \mathrm{WIN} 35428)$ in the monkey brain. Synapse 6: $189-195$.

De Vries TJ, Schoffelmeer AN, Binnekade R, Vanderschuren LJ (1999). Dopaminergic mechanisms mediating the incentive to seek cocaine and heroin following long-term withdrawal of IV drug self-administration. Psychopharmacology (Berl) 143: 254-260.

Farfel GM, Kleven MS, Woolverton WL, Seiden LS, Perry BD (1992). Effects of repeated injections of cocaine on catecholamine receptor binding sites, dopamine transporter binding sites and behavior in rhesus monkey. Brain Res 578: 235-243.

Graham J, Porrino LJ (1995). Neuroanatomical Substrates of Cocaine Self-Administration. CRC: Boca Raton, FL.

Hemby SE, Co C, Koves TR, Smith JE, Dworkin SI (1997). Differences in extracellular dopamine concentrations in the nucleus accumbens during response-dependent and response- independent cocaine administration in the rat. Psychopharmacology (Berl) 133: 7-16.

Henry DJ, White FJ (1991). Repeated cocaine administration causes persistent enhancement of D1 dopamine receptor sensitivity within the rat nucleus accumbens. J Pharmacol Exp Ther 258: 882-890.

Jacobsen LK, Staley JK, Malison RT, Zoghbi SS, Seibyl JP, Kosten TR et al (2000). Elevated central serotonin transporter binding availability in acutely abstinent cocaine-dependent patients. Am J Psychiatry 157: 1134-1140.

Khroyan TV, Barrett-Larimore RL, Rowlett JK, Spealman RD (2000). Dopamine D1- and D2-like receptor mechanisms in relapse to cocaine-seeking behavior: effects of selective antagonists and agonists. J Pharmacol Exp Ther 294: 680-687.

Khroyan TV, Platt DM, Rowlett JK, Spealman RD (2003). Attenuation of relapse to cocaine seeking by dopamine D1 receptor agonists and antagonists in non-human primates. Psychopharmacology (Berl) 168: 124-131.

Laruelle M (2000). Imaging synaptic neurotransmission with in vivo binding competition techniques: a critical review. J Cereb Blood Flow Metab 20: 423-451.

Letchworth SR, Nader MA, Smith HR, Friedman DP, Porrino LJ (2001). Progression of changes in dopamine transporter binding site density as a result of cocaine self-administration in rhesus monkeys. J Neurosci 21: 2799-2807.

Lidow MS, Goldman-Rakic PS, Gallager DW, Rakic P (1991). Distribution of dopaminergic receptors in the primate cerebral cortex: quantitative autoradiographic analysis using [3H]raclopride, $[3 \mathrm{H}]$ spiperone and $[3 \mathrm{H}] \mathrm{SCH}$ 23390. Neuroscience 40: 657-671.

Little KY, Elmer LW, Zhong H, Scheys JO, Zhang L (2002). Cocaine induction of dopamine transporter trafficking to the plasma membrane. Mol Pharmacol 61: 436-445.

Little KY, Krolewski DM, Zhang L, Cassin BJ (2003). Loss of striatal vesicular monoamine transporter protein (VMAT2) in human cocaine users. Am J Psychiatry 160: 47-55.

Little KY, Zhang L, Desmond T, Frey KA, Dalack GW, Cassin BJ (1999). Striatal dopaminergic abnormalities in human cocaine users. Am J Psychiatry 156: 238-245.

Malison RT, Best SE, van Dyck CH, McCance EF, Wallace EA, Laruelle $\mathrm{M}$ et al (1998). Elevated striatal dopamine transporters during acute cocaine abstinence as measured by [123I] beta-CIT SPECT. Am J Psychiatry 155: 832-834.

Martinez D, Broft A, Foltin RW, Slifstein M, Hwang DR, Huang Y et al (2004). Cocaine dependence and $\mathrm{d} 2$ receptor availability in the functional subdivisions of the striatum: relationship with cocaine-seeking behavior. Neuropsychopharmacology 29: 1190-1202.

Martinez D, Narendran R, Foltin RW, Slifstein M, Hwang DR, Broft A et al (2007). Amphetamine-induced dopamine release: markedly blunted in cocaine dependence and predictive of the choice to self-administer cocaine. Am J Psychiatry 164: 622-629.

Mash DC, Pablo J, Ouyang Q, Hearn WL, Izenwasser S (2002). Dopamine transport function is elevated in cocaine users. J Neurochem 81: 292-300.

Mateo Y, Lack CM, Morgan D, Roberts DC, Jones SR (2005). Reduced dopamine terminal function and insensitivity to cocaine following cocaine binge self-administration and deprivation. Neuropsychopharmacology 30: 1455-1463.

Melega WP, Jorgensen MJ, Lacan G, Way BM, Pham J, Morton G et al (2008). Long-term methamphetamine administration in the vervet monkey models aspects of a human exposure: brain neurotoxicity and behavioral profiles. Neuropsychopharmacology 33: 1441-1452.

Moore RJ, Vinsant SL, Nader MA, Porrino LJ, Friedman DP (1998a). Effect of cocaine self-administration on striatal dopamine D1 receptors in rhesus monkeys. Synapse 28: 1-9. 
Moore RJ, Vinsant SL, Nader MA, Porrino LJ, Friedman DP (1998b). Effect of cocaine self-administration on dopamine D2 receptors in rhesus monkeys. Synapse 30: 88-96.

Morgan D, Grant KA, Gage HD, Mach RH, Kaplan JR, Prioleau O et al (2002). Social dominance in monkeys: dopamine D2 receptors and cocaine self-administration. Nat Neurosci 5: 169-174.

Nader MA, Czoty PW (2008). Brain imaging in nonhuman primates: insights into drug addiction. ILAR J 49: 89-102.

Nader MA, Daunais JB, Moore T, Nader SH, Moore RJ, Smith HR et al (2002). Effects of cocaine self-administration on striatal dopamine systems in rhesus monkeys: initial and chronic exposure. Neuropsychopharmacology 27: 35-46.

Nader MA, Morgan D, Gage HD, Nader SH, Calhoun TL, Buchheimer $\mathrm{N}$ et al (2006). PET imaging of dopamine D2 receptors during chronic cocaine self-administration in monkeys. Nat Neurosci 9: 1050-1056.

Nolan EB, Harrison LM, Lahoste GJ, Ruskin DN (2007). Behavioral synergism between $\mathrm{D}(1)$ and $\mathrm{D}(2)$ dopamine receptors in mice does not depend on gap junctions. Synapse 61: 279-287.

Porrino LJ, Lyons D, Miller MD, Smith HR, Friedman DP, Daunais JB et al (2002). Metabolic mapping of the effects of cocaine during the initial phases of self-administration in the nonhuman primate. J Neurosci 22: 7687-7694.

Porrino LJ, Lyons D, Smith HR, Daunais JB, Nader MA (2004). Cocaine self-administration produces a progressive involvement of limbic, association, and sensorimotor striatal domains. J Neurosci 24: 3554-3562.

Ruskin DN, Bergstrom DA, Walters JR (1999). Multisecond oscillations in firing rate in the globus pallidus: synergistic modulation by D1 and D2 dopamine receptors. J Pharmacol Exp Ther 290: 1493-1501.

Samuvel DJ, Jayanthi LD, Manohar S, Kaliyaperumal K, See RE, Ramamoorthy S (2008). Dysregulation of dopamine transporter trafficking and function after abstinence from cocaine selfadministration in rats: evidence for differential regulation in caudate putamen and nucleus accumbens. J Pharmacol Exp Ther 325: 293-301.

Schmidt HD, Anderson SM, Pierce RC (2006). Stimulation of D1-like or D2 dopamine receptors in the shell, but not the core, of the nucleus accumbens reinstates cocaine-seeking behaviour in the rat. Eur J Neurosci 23: 219-228.

Self DW, Barnhart WJ, Lehman DA, Nestler EJ (1996). Opposite modulation of cocaine-seeking behavior by D1- and D2-like dopamine receptor agonists. Science 271: 1586-1589.

Staley JK, Hearn WL, Ruttenber AJ, Wetli CV, Mash DC (1994). High affinity cocaine recognition sites on the dopamine transporter are elevated in fatal cocaine overdose victims. J Pharmacol Exp Ther 271: 1678-1685.

Volkow ND, Fowler JS, Wang GJ, Hitzemann R, Logan J, Schlyer DJ et al (1993). Decreased dopamine D2 receptor availability is associated with reduced frontal metabolism in cocaine abusers. Synapse 14: 169-177.

Volkow ND, Wang GJ, Fowler JS, Logan J, Gatley SJ, Gifford A et al (1999). Prediction of reinforcing responses to psychostimulants in humans by brain dopamine D2 receptor levels. Am J Psychiatry 156: 1440-1443.

Volkow ND, Wang GJ, Fowler JS, Logan J, Gatley SJ, Hitzemann R et al (1997). Decreased striatal dopaminergic responsiveness in detoxified cocaine-dependent subjects. Nature 386: 830-833.

Walters JR, Bergstrom DA, Carlson JH, Chase TN, Braun AR (1987). D1 dopamine receptor activation required for postsynaptic expression of D2 agonist effects. Science 236: 719-722.

Weiss F, Martin-Fardon R, Ciccocioppo R, Kerr TM, Smith DL, Ben-Shahar O (2001). Enduring resistance to extinction of cocaine-seeking behavior induced by drug-related cues. Neuropsychopharmacology 25: 361-372.

Wong DF, Kuwabara H, Schretlen DJ, Bonson KR, Zhou Y, Nandi A et al (2006). Increased occupancy of dopamine receptors in human striatum during cue-elicited cocaine craving. Neuropsychopharmacology 31: 2716-2727. 